\title{
Design of an Optimally-Diagnostic Skin Test for Diagnosis of Sensitivity to Eight Allergens: A First-in-Human Study of Dose Escalation and Simultaneous Administration in Chinese Subjects
}

This article was published in the following Dove Press journal:

Journal of Asthma and Allergy

\author{
Xiaoyi Ning (D) ${ }^{1, *}$ \\ Yun Kuang ${ }^{1, *}$ \\ Shuwei Zhao ${ }^{2}$ \\ Wenjing $\mathrm{Hou}^{2}$ \\ Guoping Yang (iD) 1,3,4 \\ Xuerui Zhu ${ }^{5}$ \\ Ruiling Liu ${ }^{6}$ \\ Jie Huang'
}

'Center of Clinical Pharmacology, The Third Xiangya Hospital, Central South University, Changsha, Hunan, People's Republic of China; ${ }^{2}$ Center of Clinical Medical Trial, Medical University General Hospital, Tianjin, People's Republic of China; ${ }^{3}$ Research Center for Drug Clinical Evaluation of Central South University, Changsha, Hunan, People's Republic of China; ${ }^{4}$ Department of Pharmacy, The Third Xiangya Hospital, Central South University, Changsha, Hunan, People's Republic of China; ${ }^{5}$ Department of clinical research and development, Zhejiang Wolwo Biopharmaceuticals, Deqing, Zhejiang, People's Republic of China;

${ }^{6}$ Department of Allergy, Medical University General Hospital, Tianjin, People's Republic of China

*These authors contributed equally to this work

Correspondence: Ruiling Liu

Department of Allergy, Medical University

General Hospital, Tianjin 300052, People's

Republic of China

$\mathrm{Tel} / \mathrm{Fax}+86 / 8622930966$

Email Irly05@I63.com

Jie Huang

Center for Clinical Pharmacology, The

Third Xiangya Hospital, Central South

University, I 38 TongZiPo Road, Changsha,

Hunan 4I00I3, People's Republic of China

$\mathrm{Tel} / \mathrm{Fax}+86 / 5 \mathrm{II} 6469024$

Email cellahuang1988@I63.com
Background: Eight extracts from common native allergens, Artemisia annua pollen, Platanus pollen, Humulus pollen, Betula platyphylla pollen, Ambrosia artemisiifolia pollen, Blattella germanica, cat dander and dog dander were developed for skin prick test (SPT). Since standardization and composition alone cannot guarantee that the allergen extracts are within the concentration range that give the best chance of a true diagnosis, it is necessary to explore the optimal diagnostic concentration (ODC) of allergens in SPT.

Objective: To identify the optimal diagnostic concentration of eight allergen extracts in SPT and assess the safety of simultaneous administration.

Patients and Methods: Patients with a history of allergic disease were enrolled in this twopart open-label, parallel study. In Study 1, 92 patients were enrolled into eight groups according to their disease-causing allergens and were given three increasing concentrations of the corresponding allergen. In Study 2, 20 patients were divided into two concentration groups and were given all of the eight allergens. Safety and sensitivity were evaluated to determine the optimal diagnostic concentration.

Results: In Study 1, the sensitivity of seven allergen extracts was $>80 \%$ at middle and high concentrations, except for Ambrosia artemisiifolia pollen. The optimal diagnostic concentration (in DU/mL) for eight allergens was 33,333, 12,000, 8667, 50,000, 40,000, 3333, 7000, and 5000. In Study 2, the prevalence of adverse events in the two groups was $70 \%$ and $80 \%$, respectively. A total of 10 wheals of 8 patients did not subside $<24 \mathrm{~h}$ after SPTs.

Conclusion: The eight allergens showed high sensitivity and safety at a certain concentration, which was defined as optimal diagnostic concentration. The results support further clinical research of investigated allergens and our study offers a scheme to determine the ODC of allergens in SPT.

Keywords: skin prick test, allergen, optimal diagnostic concentration

\section{Introduction}

Identification of disease-causing allergens is important for the accurate diagnosis of immunoglobulin E (IgE)-associated allergy. The latter is the most common and important immunologically mediated hypersensitivity disease, and affects $\sim 30 \%$ of the population worldwide. ${ }^{1-3}$ Usually, the specific diagnosis of IgE-associated allergy is based on the correlation between clinical symptoms and medical history supplemented by diagnostic tests, such as analyses of circulating specific 
immunoglobulin E (sIgE) antibodies in serum and the skin prick test (SPT). ${ }^{4}$ SPT is usually the preferred test in the diagnostic workup for allergic diseases because of its reliability, safety, convenience, and low cost. ${ }^{5-7}$

A wide variety of factors can influence the result of the SPT in clinical practice, in which the quality of the allergen extract is the main factor. The composition, total potency, and size of the SPT reaction can vary, despite being from the same allergen source. ${ }^{8,9}$ Therefore, the availability of a wide range of high-quality allergen extracts is very important for reliable results. ${ }^{10}$ Allergen extracts have standardized requirements, but few extracts that meet such requirements are available. Also, the reliability of various commercial non-standardized allergen extract has been questioned. ${ }^{11}$ In some European countries (eg, Germany), certain commercial extracts are no longer available due to the requirements for quality control. In the USA, only 19 of $>1000$ diagnostic and therapeutic extracts have a standardized potency. ${ }^{12}$ In China, most SPT solutions are hospital preparations. In addition, the standardized allergen extracts from European or the USA may not be applicable to Asian individuals. The specific allergens responsible for sensitization are different geographically because their nature and number vary with location, temperature, and climate. ${ }^{13}$

Besides, standardization and composition alone do not necessarily ensure that the allergen extracts used for SPTs are of an appropriate concentration to minimize the possibility of false positive and false negative skin reactions. ${ }^{14}$ However, there is no standard guideline for pre-market research on diagnostic allergen extracts, and clinical studies have paid scant attention to the optimal diagnostic concentration (ODC) of allergen extracts.

We wished to design a first-in-human diagnostic skin test in a small study cohort to identify the ODC for eight standardized extracts from common native allergens (Artemisia annua pollen; Platanus pollen; Humulus pollen; Betula platyphylla pollen; Ambrosia artemisiifolia pollen; Blattella germanica; cat dander; dog dander) in patients with allergic disease. We also assessed the safety of simultaneous administration of these eight standardized extracts to support clinical screening of allergens.

\section{Materials and Methods}

\section{Study Population}

Patients aged 18-45 years of both sexes who had a history of an allergic disease were enrolled. Women of childbearing age had to have a negative pregnancy test result ( $\beta$-human chorionic gonadotropin in serum). Patients were invited for a preliminary assessment to evaluate their serum sIgE concentration (UniCAP®) Phadia, Stockholm, Sweden) of the eight investigated allergens.

For Study 1, patients with a SIgE concentration of one of the eight allergens within 0.70-49.9 kilo units of allergen per liter $(\mathrm{kUA} / \mathrm{L})$ were enrolled. For Study 2, patients had to have a sIgE concentration for at least two types of the eight allergens within $0.70-100 \mathrm{kUA} / \mathrm{L}$. Besides, patients enrolled in Study 1 had to pass the SPT for Dermatophagoides farinae detection (Zhejiang Wolwo Biopharmaceuticals, Zhejiang, China), whereby the wheal diameter was $\geq 3 \mathrm{~mm}$ for the positive control solution and no wheal was present for the negative control solution (redness was allowed).

The exclusion criteria were patients: with orthostatic hypotension; a history of post phlebotomy adverse reaction; intolerant to skin pricks; with the symptoms of angioedema; with contraindications to adrenaline; who are pregnant or lactating; with severe allergic reactions or anaphylactic shock; with a history of asthma; who had used antihistamine drugs within the last 7 days; who had used phenothiazinebased drugs or imipramine-based antidepressants within 30 days before the trial; being treated with beta blockers or angiotensin-converting enzyme inhibitors; who had undergone phototherapy within 30 days; who had used glucocorticoids within the last 2 days; with skin scratches; with skin infections, dermatitis, or pathologic changes on both forearms; with a recent history of drug/alcohol abuse; who had used tobacco- or nicotine-containing products within 3 months before study initiation.

The study protocol was approved by the independent Ethics Committee of the Third Xiangya Hospital of Central South University (Changsha, China) and the ethics committee of Tianjin Medical University General Hospital (Tianjin, China). It was undertaken in accordance with the principles enshrined in the Declaration of Helsinki 1964 and its later amendments. This clinical trial is registered on www.chictr.org.cn (ChiCTR1900023952). All participants provided written informed consent before study initiation.

\section{Skin Test Material}

Eight SPT solutions were tested: Artemisia annua pollen, Platanus pollen, dog dander, Betula platyphylla pollen, cat dander, Humulus pollen, Blattella germanica and Ambrosia artemisiifolia pollen. The test products were provided in vials containing different concentrations of 
each allergen. Histamine phosphate $(1.70 \mathrm{mg} / \mathrm{mL})$ was used as the positive control and glycerin saline solution $(\mathrm{v} / \mathrm{v}=1: 1)$ as the negative control solution. All SPT solutions and positive and negative controls were manufactured by Zhejiang Wolwo Biopharmaceuticals.

\section{Study I}

Study 1 was an open-label parallel study to investigate the sensitivity of patients to a single allergen within one concentration range at two centers in China. Patients with a serum $\operatorname{sgE}$ concentration of the allergen within 0.70-$49.9 \mathrm{kUA} / \mathrm{L}$ were enrolled into corresponding allergen groups. SPTs with a single allergen as well as positive and negative controls were carried out simultaneously and patients were followed up for $\leq 24 \mathrm{~h}$. After a washout period of $48 \mathrm{~h}$, the next concentration of SPT solution was given. The test products contained three concentrations of each allergen increasing in three steps, and the concentration of each SPT solution is shown in Table 1.

\section{Study 2}

Study 2 was a single-center, open-label parallel study to investigate the tolerance of patients to a combination of eight allergens at two concentrations. Patients with a serum $\operatorname{sIgE}$ concentration within $0.70-100 \mathrm{kUA} / \mathrm{L}$ for at least two types of the eight allergens were enrolled.

Table I Increase in Concentrations in Three Steps of Each Allergen Extract in Study I

\begin{tabular}{|l|l|l|l|}
\hline Allergen Extract & $\begin{array}{l}\text { Conc.I } \\
\text { (DU/mL) }\end{array}$ & $\begin{array}{l}\text { Conc.2 } \\
\text { (DU/mL) }\end{array}$ & $\begin{array}{l}\text { Conc.3 } \\
\text { (DU/mL) }\end{array}$ \\
\hline $\begin{array}{l}\text { Artemisia annua pollen } \\
\text { (group A) }\end{array}$ & 33,333 & 100,000 & 300,000 \\
\hline Platanus pollen (group B) & 4000 & 12,000 & 36,000 \\
\hline Dog dander (group C) & 8667 & 26,000 & 78,000 \\
\hline $\begin{array}{l}\text { Betula platyphylla pollen } \\
\text { (group D) }\end{array}$ & 16,667 & 50,000 & 150,000 \\
\hline Cat dander (group E) & 13,333 & 40,000 & 120,000 \\
\hline $\begin{array}{l}\text { Humulus pollen (group } \\
\text { F) }\end{array}$ & 3333 & 10,000 & 30,000 \\
\hline $\begin{array}{l}\text { Blattella germanica } \\
\text { (group G) }\end{array}$ & 2333 & 7000 & 21,000 \\
\hline $\begin{array}{l}\text { Ambrosia artemisiifolia } \\
\text { pollen (group H) }\end{array}$ & 1667 & 5000 & 15,000 \\
\hline
\end{tabular}

Abbreviation: Conc., concentration.
SPTs with those eight allergens as well as positive and negative controls were undertaken simultaneously, and patients were followed up for $\leq 24 \mathrm{~h}$. Each allergen in Study 2 comprised two concentration groups. The ODC in Study 1 was selected as Conc. 1 for group 1, and the triple ODC was selected as Conc.2 for group 2. The two concentrations for each SPT solution are shown in Table 2. The test for group 1 was started first and, if there was no event that met the criteria for study termination, then the test for group 2 was done.

\section{Skin Prick Test}

SPTs were carried out on the volar sides of forearms. The investigated allergens as well as positive and negative controls were tested. The test areas were numbered by a skin marker and had a minimum distance of $3 \mathrm{~cm}$ to each other. The skin was pricked lightly and rapidly vertically through one drop of the SPT solution by means of a microlancette. A new microlancette was used for each prick.

An absorbent paper towel was laid on the skin-prick area and pressed carefully 3 min after the SPT. The wheal outline was read after 15-20 min. The wheal outline was traced with a ballpoint pen, and then removed from the skin. The wheal outline was documented by sticking it to paper containing grids using a broad piece of translucent tape. The mean diameter $(\mathrm{Y})$ was recorded as: $\mathrm{Y}=(\mathrm{D}+$ d) $/ 2$, where the longest diameter of the wheal was D and the mid-vertical line of the longest diameter was $d$. Then the area of the original wheal was preserved as an image.

Table 2 The Two Concentrations of Each Allergen Extract Used in Study 2

\begin{tabular}{|l|l|l|}
\hline Allergen Extract & $\begin{array}{l}\text { Group I (DU/ } \\
\mathbf{m L})\end{array}$ & $\begin{array}{l}\text { Group 2 (DU/ } \\
\mathbf{m L})\end{array}$ \\
\hline Artemisia annua pollen & 33,333 & 100,000 \\
\hline Platanus pollen & 12,000 & 36,000 \\
\hline Dog dander & 8667 & 26,000 \\
\hline Betula platyphylla pollen & 50,000 & 150,000 \\
\hline Cat dander & 40,000 & 120,000 \\
\hline Humulus pollen & 3333 & 10,000 \\
\hline Blattella germanica & 7000 & 21,000 \\
\hline $\begin{array}{l}\text { Ambrosia artemisiifolia } \\
\text { pollen }\end{array}$ & 5000 & 15,000 \\
\hline
\end{tabular}


For a positive SPT reaction, the wheal had to be $\geq 3 \mathrm{~mm}$ in diameter. A valid SPT result also required a positive reaction to histamine $(\geq 3 \mathrm{~mm})$ and a negative control reaction to saline $(<3 \mathrm{~mm}){ }^{15}$

\section{Estimation of Sensitivity and the ODC}

The estimation of sensitivity was carried out in Study 1. The number of patients with a positive SPT result at different concentrations of each allergen was counted to calculate the positive rate, ie, the sensitivity of the allergen. The sensitivity of each concentration of the eight allergens was estimated based on the number of patients with a valid SPT result (wheal diameter $\geq 3 \mathrm{~mm}$ ) divided by the number of patients with a positive SPT result. The ODC for each allergen was investigated by determination of the sensitivity for each concentration. Besides, the wheal diameter at different concentrations of each allergen was compared to evaluate the relationship between allergen exposure and the allergic reaction.

\section{Safety Assessments}

Both Study 1 and Study 2 were included in safety analyses. Safety assessments comprised physical examination, vital signs, 12-lead electrocardiography, as well as routine hematology and urinary measurements. Adverse events (AEs) were evaluated in terms of intensity, duration, severity, outcomes, and association with the investigated allergen extracts. Adverse events were monitored throughout the study.

The wheal or itchiness that appeared in the skin prick area $<24 \mathrm{~h}$ after the SPT was not considered as an AE but, if it was present $>24 \mathrm{~h}$, then it was considered to be an AE.

\section{Statistical Analyses}

Sensitivity and safety analyses were descriptive. All patients exposed to any investigated allergens comprised the population used for safety assessment. All patients with a valid SPT result in Study 1 were evaluated for sensitivity analyses. Related-samples Friedman's two-way analysis was used to evaluate the difference in wheal diameter between different concentrations of each allergen. SPSS 26 (IBM, Armonk, NY, USA) was employed for statistical analyses. $\mathrm{P}<0.05$ was considered significant.

\section{Results}

\section{Patients}

Study 1 was conducted between 9 July 2018 and 1 March 2019. As shown in Figure 1, 92 patients were enrolled, of which 90 received at least one SPT of investigated allergens in Study 1. Patients were aged 18-42 years and had body mass index (BMI) of $23.90 \pm$

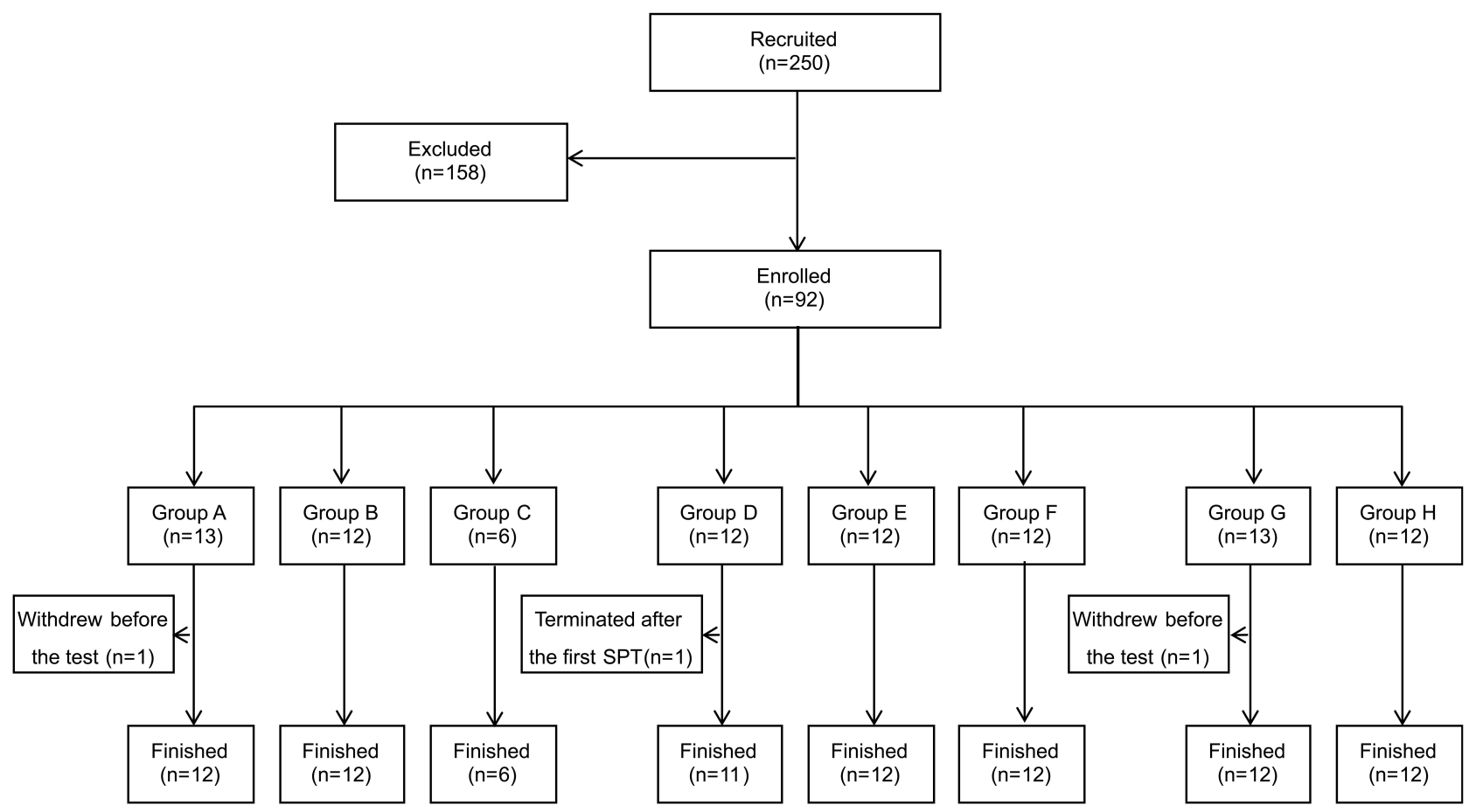

Figure I Flow diagram of Study I. 


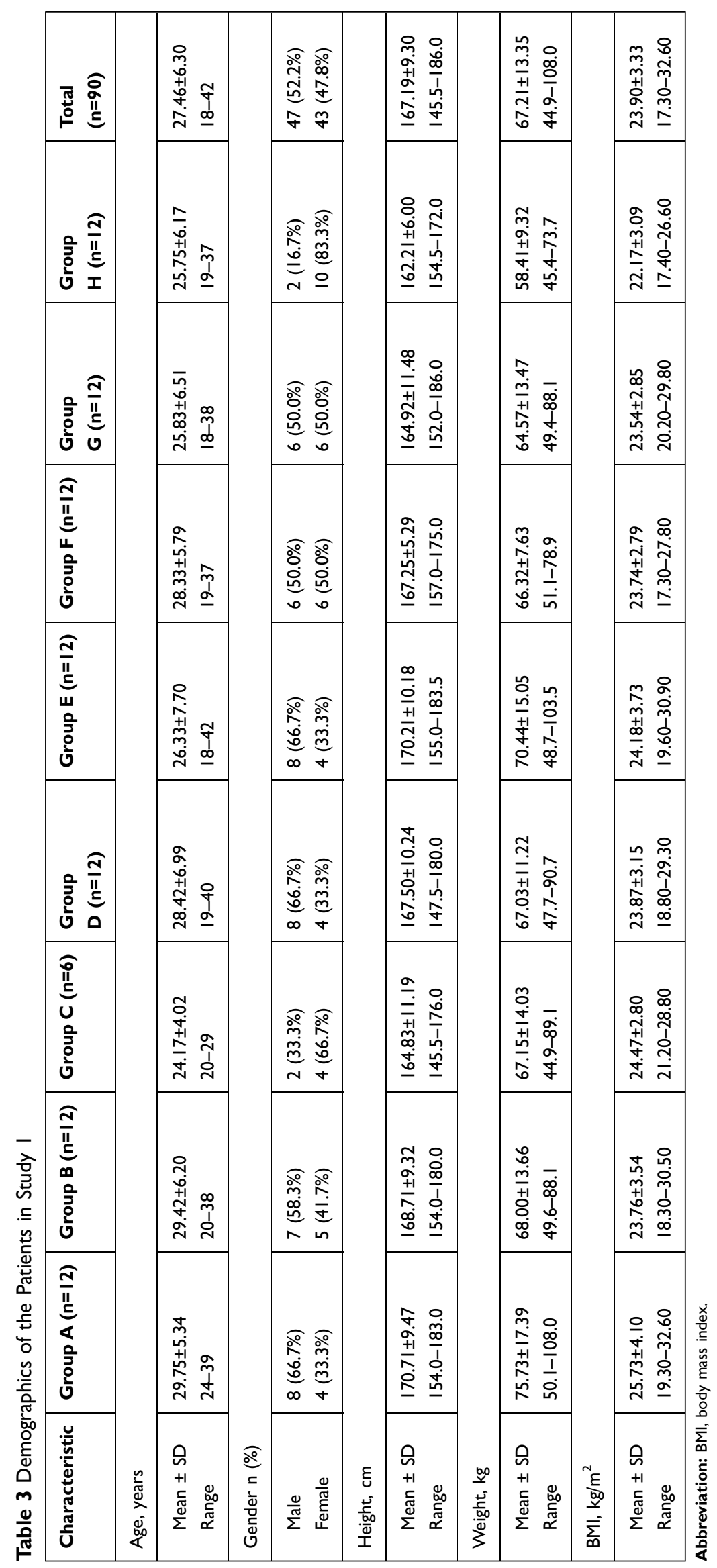


$3.33 \mathrm{~kg} / \mathrm{m}^{2}$. The characteristics of people at baseline in Study 1 are given in Table 3. These 90 individuals received the SPT of all three concentrations except for one person in group D for whom the wheal did not subside $48 \mathrm{~h}$ after receiving the SPT of Conc. 1 and for whom a subsequent concentration test was not done.

A further 20 patients were included and completed Study 2 (Figure 2) from 16 July $16 \quad 2019$ to 14 September 2019. They were aged 18-38 years and the BMI was $22.33 \pm 3.16 \mathrm{~kg} / \mathrm{m}^{2}$. The characteristics of patients at baseline in Study 2 are given in Table 4.

\section{Estimation of Sensitivity and the ODC}

The sensitivity of each allergen at different concentrations is outlined in Table 5. Among them, the positive rates of dog dander and Humulus pollen were $100 \%$ at all three concentrations. The positive rates of Artemisia annua pollen, cat dander and Blattella germanica were $100 \%$ at Conc. 2 and Conc.3, as well as $91.67 \%, 75.00 \%$ and $54.55 \%$ at Conc. 1 , respectively. The positive rates of Platanus pollen were $36.36 \%, 91.67 \%$ and $100 \%$, respectively, to Betula platyphylla pollen were $72.73 \%, 80.00 \%$ and $100 \%$, and to Ambrosia artemisiifolia pollen were $30.00 \%, 91.67 \%$ and $72.73 \%$, respectively, at Conc.1, Conc. 2 and Conc.3. Based on safety and sensitivity, the ODC (in development units $(\mathrm{DU}) / \mathrm{mL})$ for each allergen was $33,333,12,000,8667$,

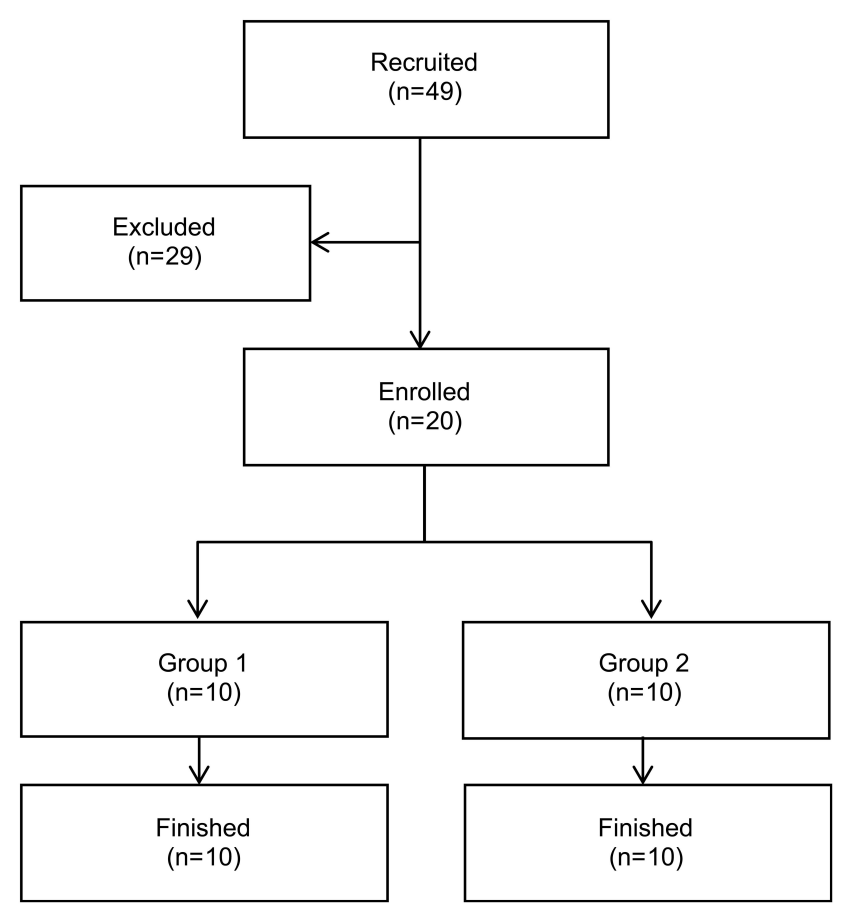

Figure 2 Flow diagram of Study 2.
Table 4 Demographics of the Patients in Study 2

\begin{tabular}{|c|c|c|c|}
\hline Characteristic & $\begin{array}{l}\text { Group I } \\
(n=10)\end{array}$ & $\begin{array}{l}\text { Group } 2 \\
(n=10)\end{array}$ & $\begin{array}{l}\text { Total } \\
(n=20)\end{array}$ \\
\hline \multicolumn{4}{|l|}{ Age, years } \\
\hline $\begin{array}{l}\text { Mean } \pm \text { SD } \\
\text { Range }\end{array}$ & $\begin{array}{l}25.30 \pm 5.73 \\
20-36\end{array}$ & $\begin{array}{l}25.30 \pm 7.02 \\
18-38\end{array}$ & $\begin{array}{l}25.30 \pm 6.24 \\
18-38\end{array}$ \\
\hline \multicolumn{4}{|l|}{ Gender n (\%) } \\
\hline $\begin{array}{l}\text { Male } \\
\text { Female }\end{array}$ & $\begin{array}{l}4(40 \%) \\
6(60 \%)\end{array}$ & $\begin{array}{l}3(30 \%) \\
7(70 \%)\end{array}$ & $\begin{array}{l}7(35 \%) \\
13(65 \%)\end{array}$ \\
\hline \multicolumn{4}{|l|}{ Height, cm } \\
\hline $\begin{array}{l}\text { Mean } \pm S D \\
\text { Range }\end{array}$ & $\begin{array}{l}\mid 67.60 \pm 9.57 \\
|52.0-18| .5\end{array}$ & $\begin{array}{l}165.25 \pm 8.88 \\
\mid 55.5-184.5\end{array}$ & $\begin{array}{l}166.43 \pm 9.07 \\
152.0-184.5\end{array}$ \\
\hline \multicolumn{4}{|l|}{ Weight, kg } \\
\hline $\begin{array}{l}\text { Mean } \pm \text { SD } \\
\text { Range }\end{array}$ & $\begin{array}{l}64.32 \pm 12.94 \\
45.6-80.5\end{array}$ & $\begin{array}{l}60.20 \pm 12.28 \\
44.7-79.3\end{array}$ & $\begin{array}{l}62.26 \pm 12.46 \\
44.7-80.5\end{array}$ \\
\hline \multicolumn{4}{|l|}{ BMI, $\mathrm{kg} / \mathrm{m}^{2}$} \\
\hline $\begin{array}{l}\text { Mean } \pm \text { SD } \\
\text { Range }\end{array}$ & $\begin{array}{l}22.76 \pm 3.40 \\
17.7-28.6\end{array}$ & $\begin{array}{l}21.89 \pm 3.0 \mid \\
\mid 8.3-25.8\end{array}$ & $\begin{array}{l}22.33 \pm 3.16 \\
17.7-28.6\end{array}$ \\
\hline
\end{tabular}

Abbreviation: BMI, body mass index.

Table 5 The Sensitivity of Each Allergen Extract at Different Concentrations

\begin{tabular}{|c|c|c|c|}
\hline \multirow[t]{2}{*}{ Allergen Extract } & \multicolumn{3}{|c|}{ Positive Rate, \%(n/N) } \\
\hline & Conc.I & Conc. 2 & Conc.3 \\
\hline $\begin{array}{l}\text { Artemisia annua pollen } \\
\text { (group A) }\end{array}$ & $\begin{array}{l}91.67(11 / \\
12)\end{array}$ & $\begin{array}{l}100.00 \\
(12 / 12)\end{array}$ & $\begin{array}{l}100.00 \\
(11 / 11)\end{array}$ \\
\hline Platanus pollen (group B) & $\begin{array}{l}36.36(4 / \\
I I)\end{array}$ & $\begin{array}{l}91.67(11 / \\
12)\end{array}$ & $\begin{array}{l}100.00 \\
(12 / 12)\end{array}$ \\
\hline Dog dander (group C) & $\begin{array}{l}100.00(4 / \\
4)\end{array}$ & $\begin{array}{l}100.00(6 / \\
6)\end{array}$ & $\begin{array}{l}100.00(6 / \\
6)\end{array}$ \\
\hline $\begin{array}{l}\text { Betula platyphylla pollen } \\
\text { (group D) }\end{array}$ & $\begin{array}{l}72.73(8 / \\
\text { II) }\end{array}$ & $\begin{array}{l}80.00(8 / \\
10)\end{array}$ & $\begin{array}{l}100.00 \\
(11 / 11)\end{array}$ \\
\hline Cat dander (group E) & $\begin{array}{l}75.00(9 / \\
12)\end{array}$ & $\begin{array}{l}100.00 \\
(12 / 12)\end{array}$ & $\begin{array}{l}100.00 \\
(12 / 12)\end{array}$ \\
\hline Humulus pollen (group F) & $\begin{array}{l}100.00 \\
(12 / 12)\end{array}$ & $\begin{array}{l}100.00 \\
(12 / 12)\end{array}$ & $\begin{array}{l}100.00 \\
(12 / 12)\end{array}$ \\
\hline Blattella germanica (group G) & $\begin{array}{l}54.55(6 / \\
\text { II) }\end{array}$ & $\begin{array}{l}100.00 \\
(11 / 11)\end{array}$ & $\begin{array}{l}100.00(9 / \\
9)\end{array}$ \\
\hline $\begin{array}{l}\text { Ambrosia artemisiifolia pollen } \\
\text { (group } \mathrm{H} \text { ) }\end{array}$ & $\begin{array}{l}30.00(3 / \\
10)\end{array}$ & $\begin{array}{l}91.67(11 / \\
12)\end{array}$ & $\begin{array}{l}72.73(8 / \\
\mathrm{II})\end{array}$ \\
\hline
\end{tabular}

Notes: ${ }^{\text {PPositive rate }}=$ number of patients with a positive SPT result/number of patients included in sensitivity analyses.

Abbreviation: Conc., concentration. 
Table 6 Comparison of Wheal Diameter of Patients at Different Concentrations of Each Allergen Extract in Study $\mathrm{I}^{\mathrm{a}}$

\begin{tabular}{|c|c|c|c|c|c|}
\hline $\begin{array}{l}\text { Allergen } \\
\text { Extract }\end{array}$ & $\mathbf{N}$ & $\begin{array}{l}\text { Conc. I } \\
\text { (Mean } \\
\pm \text { SD) }\end{array}$ & $\begin{array}{l}\text { Conc. } 2 \\
\text { (Mean } \\
\pm \text { SD) }\end{array}$ & $\begin{array}{l}\text { Conc.3 } \\
\text { (Mean } \\
\pm \text { SD) }\end{array}$ & $\mathbf{P}$ \\
\hline $\begin{array}{l}\text { Artemisia annua } \\
\text { pollen (group A) }\end{array}$ & 11 & $\begin{array}{l}5.02 \\
\pm 1.59\end{array}$ & $\begin{array}{l}7.70 \\
\pm 1.75\end{array}$ & $\begin{array}{l}9.75 \\
\pm 2.50\end{array}$ & $<0.001 *$ \\
\hline $\begin{array}{l}\text { Platanus pollen } \\
\text { (group B) }\end{array}$ & II & $\begin{array}{l}3.04 \\
\pm 2.19\end{array}$ & $\begin{array}{l}4.36 \\
\pm 1.25\end{array}$ & $\begin{array}{l}4.95 \\
\pm 1.40\end{array}$ & $0.002 *$ \\
\hline $\begin{array}{l}\text { Dog dander } \\
\text { (group C) }\end{array}$ & 4 & $\begin{array}{l}5.38 \\
\pm 1.30\end{array}$ & $\begin{array}{l}5.88 \\
\pm 1.76\end{array}$ & $\begin{array}{l}7.12 \\
\pm 2.14\end{array}$ & 0.174 \\
\hline $\begin{array}{l}\text { Betula platyphylla } \\
\text { pollen (group D) }\end{array}$ & 9 & $\begin{array}{l}5.03 \\
\pm 3.09\end{array}$ & $\begin{array}{l}6.86 \\
\pm 3.40\end{array}$ & $\begin{array}{l}7.33 \\
\pm 3.17\end{array}$ & $0.008^{*}$ \\
\hline $\begin{array}{l}\text { Cat dander (group } \\
\text { E) }\end{array}$ & 12 & $\begin{array}{l}4.06 \\
\pm 1.96\end{array}$ & $\begin{array}{l}6.14 \\
\pm 1.55\end{array}$ & $\begin{array}{l}7.52 \\
\pm 1.79\end{array}$ & $0.001 *$ \\
\hline $\begin{array}{l}\text { Humulus pollen } \\
\text { (group F) }\end{array}$ & 12 & $\begin{array}{l}7.27 \\
\pm 1.88\end{array}$ & $\begin{array}{l}11.10 \\
\pm 4.04\end{array}$ & $\begin{array}{l}11.85 \\
\pm 3.52\end{array}$ & $0.001 *$ \\
\hline $\begin{array}{l}\text { Blattella germanica } \\
\text { (group G) }\end{array}$ & 9 & $\begin{array}{l}3.19 \\
\pm 0.87\end{array}$ & $\begin{array}{l}4.58 \\
\pm 1.12\end{array}$ & $\begin{array}{l}5.47 \\
\pm 1.97\end{array}$ & $0.003 *$ \\
\hline $\begin{array}{l}\text { Ambrosia } \\
\text { artemisiifolia pollen } \\
\text { (group } \mathrm{H})\end{array}$ & 10 & $\begin{array}{l}2.65 \\
\pm 1.32\end{array}$ & $\begin{array}{l}3.68 \\
\pm 0.64\end{array}$ & $\begin{array}{l}4.32 \\
\pm 1.74\end{array}$ & $0.003 *$ \\
\hline
\end{tabular}

Notes: ${ }^{\text {a } F r i e d m a n ~ T e s t, ~}{ }^{*} \mathrm{P}<0.05$, with statistical significance.

Abbreviation: Conc., concentration.

50,000, 40,000, 3333, 7000, and 5000, for Artemisia annua pollen, Platanus pollen, dog dander, Betula platyphylla pollen, cat dander, Humulus pollen, Blattella germanica and Ambrosia artemisiifolia pollen, respectively.

We compared the wheal diameter at different concentrations of the eight allergens (Table 6). Except for dog dander (for which the sample size was too small), the other seven allergens elicited significant differences in the wheal diameter at different concentrations. Multiple comparisons (Figure 3) showed that the wheal diameter after exposure to Artemisia annua pollen increased with an increase in concentration. Significant differences were observed between group 1 and group 2, between group 1 and group 3 , but not group 2 and group 3 in other six allergen extracts.

\section{Safety Assessments Study I}

The prevalence of AEs possibly related to allergens in Study 1 is summarized in Appendix 1 . We discovered that 43 of 90 patients $(47.8 \%)$ experienced at least one AE possibly related to an allergen. The most common AEs (occurring in $>10 \%$ of 90 patients) possibly related to an allergen were urticaria (11.1\%) and itchiness (11.1\%) in the skin prick area, as well as pruritus (18.9\%) and urticaria $(20.0 \%)$. The AEs occurred in all groups were grade 1 and there were no serious AEs possibly related to investigated allergens, so no patients withdrew from the study due to AEs. No correlation was found between the safety and the concentration of the investigated extracts.

At the three concentrations of each allergen, the wheal resolved within $24 \mathrm{~h}$ after the SPT in more than $87.8 \%$ of patients, and more than $91.1 \%$ of the patients did not feel other discomfort.

\section{Study 2}

The prevalence of AEs possibly related to allergen in Study 2 is summarized in Appendix 2.7 of 10 patients $(70.0 \%)$ in group 1 and 8 of 10 patients $(80.0 \%)$ in group 2 experienced at least one $\mathrm{AE}$ possibly related to allergens. The common AEs included urticaria (40.0\%), itchiness (35.0\%), erythema $(20.0 \%)$ and papules $(20.0 \%)$ in the skin prick area. Of all the AEs that occurred, except for allergic dermatitis that occurred in group 2 and determined to be grade 2, the others were grade 1 and no individuals withdrew from the study due to AEs. 10 wheals of 8 patients did not subside $24 \mathrm{~h}$ after the SPT (Table 7).

\section{Discussion}

The diagnostic value of an allergen extract can be assessed only with respect to a population consisting of sensitized ("true positive") and non-sensitized ("true negative") patients. ${ }^{16}$ By considering the difference between the sensitivity of non-sensitized and sensitized patients to allergens, we used only sensitized patients as subjects in this first-in-human study. Analyses of circulating serum levels of sIgE antibodies, clinical history and the SPT are considered to be standard methods to differentiate sensitized from non-sensitized patients, ${ }^{17,18}$ and to ascertain the clinical relevance of an allergen. Due to a lack of standardized allergen extracts to obtain reliable SPT results, we used medical history and the serum sIgE level as inclusion criteria for sensitized patients. However, the inclusion of sensitized patients alone meant that we could investigate only the sensitivity of allergens but not their specificity. The specificity assessment may need to be carried out in further clinical trial with more patients.

Study 1 was the first-in-human trial of the investigated allergen extracts, so each allergen extract was planned to include a little number of 12 patients and a total of 96 
Group A (Artemisia annua pollen)

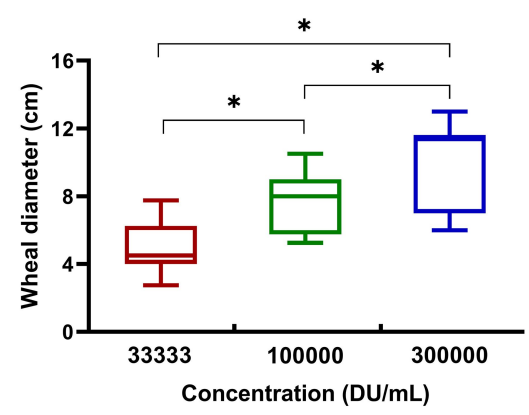

Group C (dog dander)

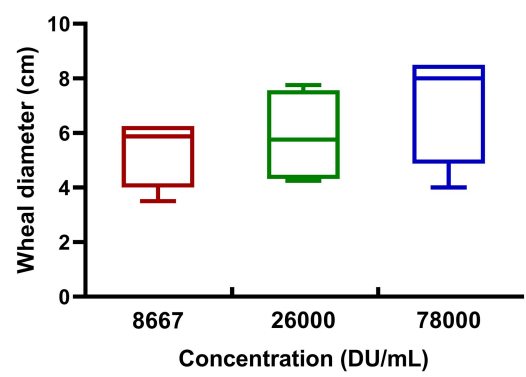

Group E (cat dander)

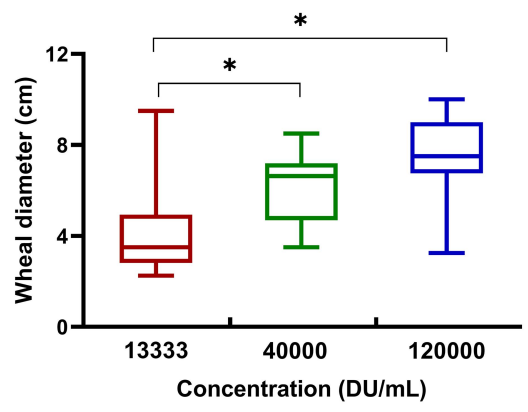

Group G (Blattella germanica)

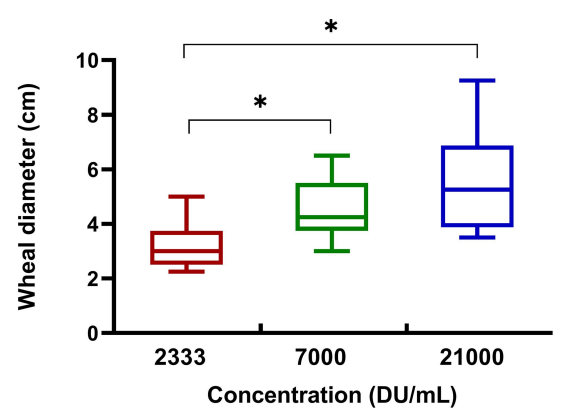

Group B (Platanus pollen)

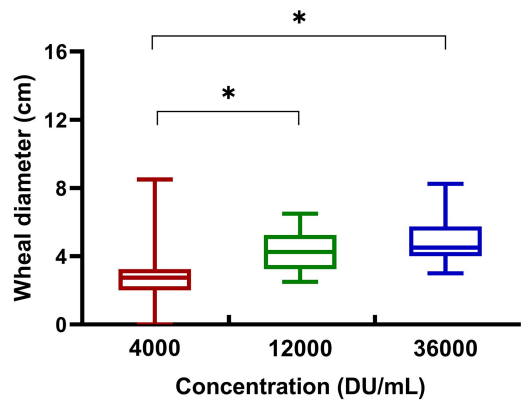

Group D (Betula platyphylla pollen)

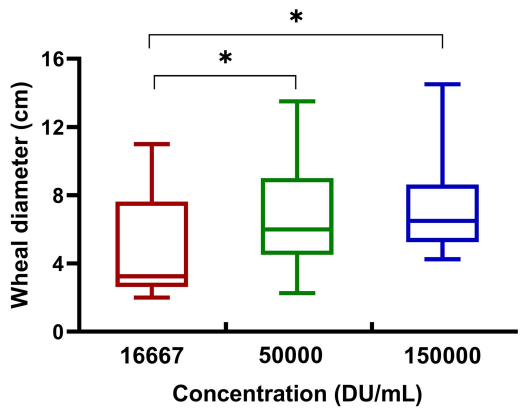

Group F (Humulus pollen)

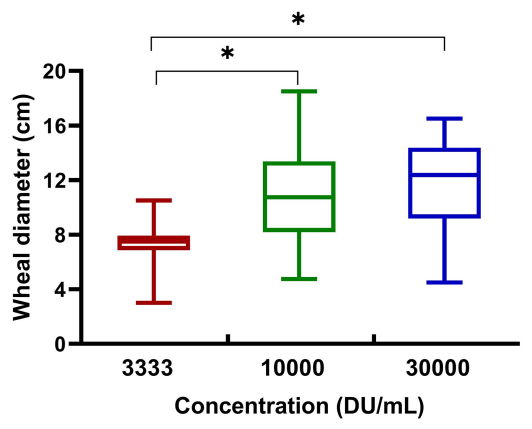

Group H (Ambrosia artemisiifolia pollen)

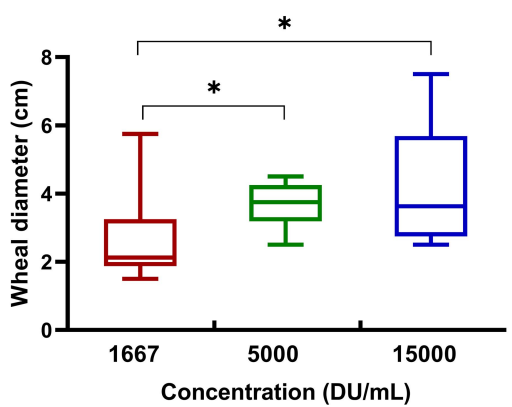

Figure 3 Comparison of wheal diameter in patients exposed to different concentrations of each allergen extract in Study I. Note: *With statistical significance. 
Table 7 Allergen Extracts That Corresponded to NonResolution of a Wheal 24h After the Skin Prick Test

\begin{tabular}{|l|l|l|l|}
\hline Allergen Extract & Group I & Group 2 & Total \\
\hline Artemisia annua pollen & $\mathrm{I}$ & 4 & 5 \\
Betula platyphylla pollen & $\mathrm{I}$ & $\mathrm{I}$ & 2 \\
Humulus pollen & 0 & 2 & 2 \\
Cat dander & 0 & $\mathrm{I}$ & $\mathrm{I}$ \\
\hline
\end{tabular}

patients were planned to be included. However, there were less people allergic to dog dander, so only 6 patients were enrolled in group C. And we did not increase the sample size because of the excellent sensitivity dog dander showed at all of the three concentrations.

The initial dose and dose gradient of each allergen were determined by deriving the human equivalent dose (HED) and based on the no-observed-adverse-effect level (NOAEL) of animal toxicology tests. Taking the safety factor 10 as the benchmark, the maximum recommended starting dose (MRSD) was set as HED/10. The minimum dose (Conc.1 of each allergen in Study 1) should be less than the MRSD, and the maximum dose (Conc. 3 of each allergen in Study 1) should be less than the HED.

The 'average diameter method' was used to characterize wheals in our study. Recently, another method 'scanned area method' has been applied for the actual size. $^{16,19}$ van der Valk ${ }^{20}$ evaluated the two methods, and found that the latter may be more accurate theoretically in determining the wheal area than the average diameter method' and was recommended in academic research. However, in clinical practice, the 'average diameter method' could also provide a similar accuracy in predicting allergic reactions and may be more convenient.

The analyses of the sensitivity of each allergen at different concentrations showed that the positive rates of seven allergen extracts were $>80 \%$ at middle and high concentrations except for Ambrosia artemisiifolia pollen (72.73\% at high concentration). The decrease of the sensitivity from middle concentration group to high concentration group might be an error caused by the small sample size of Ambrosia artemisiifolia pollen. Based on safety and sensitivity, the ODC (in DU/mL) for Artemisia annua pollen, Platanus pollen, dog dander, Betula platyphylla pollen, cat dander, Humulus pollen, Blattella germanica and Ambrosia artemisiifolia pollen was determined to be $33,333,12,000,8667,50,000,40,000,3333,7000$, and 5000 , respectively. And the ODC have been used in Phase III clinical trials. The wheal diameter in patients exposed to the middle concentration and high concentration of the allergens was larger than that in patients exposed to the low concentration, while there was no difference between the middle concentration group and high concentration group. These data suggested that the wheal diameter might be dependent on a certain concentration range of the investigated allergens, but it no longer increases when reached to a certain concentration, which is also consistent with the similar sensitivity between the middle and high concentration groups. It indicated that the sensitivity of an allergen extract was affected by its concentration. Hence, finding an appropriate concentration at which the sensitivity and safety of an allergen extract can be guaranteed is important.

There are few studies evaluating the safety of allergen diagnostic skin test in human comprehensively. Since SPT is similar to Allergen-Specific Immunotherapy (ASIT) in the mechanism of action, we assessed the safety of allergen extracts in reference to the safety of $\mathrm{ASIT}^{21}$ and the instructions of the allergen extracts. Study 1 and Study 2 suggested that the eight investigated allergens showed good safety even at a high concentration and did not reach dose-limiting toxicity (DLT) whether used alone or in combination. In Study 2, based on non-resolution of wheals $24 \mathrm{~h}$ after the SPT, except for Artemisia annua pollen and Humulus pollen (for which the safety in group 1 was better than that in group 2), the safety of other allergen extracts showed no significant difference between the two groups. However, due to the small study cohort in Study 2, a definitive conclusion of safety cannot be provided. A larger sample size is necessary to further confirm the effectiveness and safety of the combination of allergen extracts and evaluate the relationship between benefits and risks in the follow-up clinical trials.

As there are no more pre-market clinical research studies or guidelines for diagnostic allergen extracts, we designed a study to determine the ODC of the eight investigated allergens with fewer patients for further clinical studies. The small sample size helped reduce the risks and costs of the Phase I clinical trial. Besides, the safety of the simultaneous administration of eight allergens also promotes its clinical practice in allergen screening. And it is gratifying that the ODCs of this phase I clinical trial have been used in the Phase III clinical trials of eight allergens.

\section{Conclusion}

This study offers a scheme to determine the ODC of allergens in a small study cohort. The ODC of this phase 
I clinical trial have been used in the Phase III clinical trials of the eight investigated allergens.

\section{Data Sharing Statement}

The raw data of this study will not be shared because of confidentiality.

\section{Ethical Approval}

The study protocol was approved by the independent Ethics Committee of the Third Xiangya Hospital of Central South University (Changsha, China) and the ethics committee of Tianjin Medical University General Hospital (Tianjin, China). It was undertaken in accordance with the principles enshrined in the Declaration of Helsinki 1964 and its later amendments.

\section{Informed Consent}

All participants signed informed consent prior to participating in this study.

\section{Acknowledgments}

This study was supported by Zhejiang Wolwo Biopharmaceuticals, the National Natural Science Foundation of China (81673519), National major new drug creation project of China (2020ZX09201010) and Natural Science Foundation of Guangdong Province (20181015528). The study sponsors had no involvement in this study. We would like to thank all trial participants including patients, clinicians, investigators, technician, and nurses. The authors declare that they have no conflict of interest.

\section{Disclosure}

Xuerui Zhu is an employee of Zhejiang Wolwo Biopharmaceuticals. The authors report no other potential conflicts of interest in this work.

Xiaoyi Ning and Yun Kuang contributed equally to this work, and should be considered joint first author.

\section{References}

1. Anto JM, Bousquet J, Akdis M, et al. Mechanisms of the development of allergy (MeDALL): introducing novel concepts in allergy phenotypes. $J$ Allergy Clin Immunol. 2017;139(2):388-399. doi:10.1016/j.jaci.2016.12.940

2. Valenta R, Karaulov A, Niederberger V, et al. Molecular aspects of allergens and allergy. Adv Immunol. 2018;138:195-256.

3. Larche M, Akdis CA, Valenta R. Immunological mechanisms of allergen-specific immunotherapy. Nat Rev Immunol. 2006;6 (10):761-771. doi:10.1038/nri1934
4. Bousquet J, Heinzerling L, Bachert C, et al. Practical guide to skin prick tests in allergy to aeroallergens. Allergy. 2012;67(1):18-24.

5. Bernstein IL, Li JT, Bernstein DI, et al. Allergy diagnostic testing: an updated practice parameter. Ann Allergy Asthma Immunol. 2008;100 (3 Suppl 3):S1-148.

6. Frati $\mathrm{F}$, Incorvaia $\mathrm{C}$, Cavaliere $\mathrm{C}$, et al. The skin prick test. $J$ Biol Regul Homeost Agents. 2018;32(1 Suppl. 1):19-24.

7. Ansotegui IJ, Melioli G, Canonica GW, et al. IgE allergy diagnostics and other relevant tests in allergy, a World Allergy Organization position paper. World Allergy Organ J. 2020;13(2):100080. doi:10.1016/j.waojou.2019.100080

8. Rueff F, Bergmann KC, Brockow K, et al. [Skin tests for diagnostics of allergic immediate-type reactions. Guideline of the German society for allergology and clinical immunology]. Pneumologie. 2011;65 (8):484-495.

9. Kleine-Tebbe J, Matricardi PM, Hamilton RG. Allergy work-up including component-resolved diagnosis: how to make allergen-specific immunotherapy more specific. Immunol Allergy Clin North Am. 2016;36(1):191-203. doi:10.1016/j.iac.2015.08.012

10. Klimek L, Hoffmann HJ, Renz H, et al. Diagnostic test allergens used for in vivo diagnosis of allergic diseases are at risk: a European perspective. Allergy. 2015;70(10):1329-1331. doi:10.1111/all.12676

11. van Kampen V, de Blay F, Folletti I, et al. EAACI position paper: skin prick testing in the diagnosis of occupational type I allergies. Allergy. 2013;68(5):580-584. doi:10.1111/all.12120

12. Slater JE, Menzies SL, Bridgewater J, et al. The US Food and Drug Administration review of the safety and effectiveness of nonstandardized allergen extracts. J Allergy Clin Immunol. 2012;129 (4):1014-1019. doi:10.1016/j.jaci.2012.01.066

13. Bousquet PJ, Chinn S, Janson C, et al. Geographical variation in the prevalence of positive skin tests to environmental aeroallergens in the European community respiratory health survey I. Allergy. 2007;62 (3):301-309. doi:10.1111/j.1398-9995.2006.01293.x

14. Wheeler AW, Jessberger B, Drachenberg KJ, Rakoski J. Design of an optimally-diagnostic skin test solution for diagnosis of sensitivity to timothy grass (Phleum pratense) pollen. Clin Exp Allergy. 1996;26 (8):897-902. doi:10.1111/j.1365-2222.1996.tb00624.x

15. Heinzerling L, Mari A, Bergmann KC, et al. The skin prick test European standards. Clin Transl Allergy. 2013;3(1):3. doi:10.1186/ 2045-7022-3-3

16. Wagner N, Rudert M. Sensitivity and specificity of standardised allergen extracts in skin prick test for diagnoses of IgE-mediated respiratory allergies. Clin Transl Allergy. 2019;9(1):8. doi:10.1186/ s13601-019-0248-9

17. Szeinbach SL, Barnes JH, Sullivan TJ, Williams PB. Precision and accuracy of commercial laboratories' ability to classify positive and/ or negative allergen-specific IgE results. Ann Allergy Asthma Immunol. 2001;86(4):373-381. doi:10.1016/S1081-1206(10)62481-7

18. Williams PB, Barnes JH, Szeinbach SL, Sullivan TJ. Analytic precision and accuracy of commercial immunoassays for specific IgE: establishing a standard. $J$ Allergy Clin Immunol. 2000;105 (6):1221-1230. doi:10.1067/mai.2000.105219

19. Sander I, Fleischer C, Meurer U, Bruning T, Raulf-Heimsoth M. Allergen content of grass pollen preparations for skin prick testing and sublingual immunotherapy. Allergy. 2009;64(10):1486-1492. doi:10.1111/j.1398-9995.2009.02040.x

20. van der Valk JP, Gerth van Wijk R, Hoorn E, et al. Measurement and interpretation of skin prick test results. Clin Transl Allergy. 2015;6 (1):8. doi:10.1186/s13601-016-0092-0

21. Alvarez-Cuesta E, Bousquet J, Canonica GW, et al. Standards for practical allergen-specific immunotherapy. Allergy. 2006;61(Suppl s82):1-20. doi:10.1111/j.1398-9995.2006.01219_1.x 


\section{Publish your work in this journal}

The Journal of Asthma and Allergy is an international, peer-reviewed open-access journal publishing original research, reports, editorials and commentaries on the following topics: Asthma; Pulmonary physiology; Asthma related clinical health; Clinical immunology and the immunological basis of disease; Pharmacological interventions and

new therapies. The manuscript management system is completely online and includes a very quick and fair peer-review system, which is all easy to use. Visit http://www.dovepress.com/testimonials.php to read real quotes from published authors. 